\title{
The Assessment of Androgenic Response of Two Nematode Resistant Pepper (Capsicum annuum L.) Genotypes
}

\author{
Flavien Shimira ${ }^{1,3, a, *}$, Davut Keleş,b, Hatıra Taşkın ${ }^{3, c}$, Kazım Abak $^{1, d}$ \\ ${ }^{l}$ Department of Horticultural Production and Marketing, Faculty of Agricultural Sciences and Technologies, European University of Lefke, \\ Lefke, North Cyprus (TRNC) \\ ${ }^{2}$ Alata Horticultural Research Institute, 33740 Erdemli/Mersin, Turkey \\ ${ }^{3}$ Department of Horticulture, Faculty of Agriculture, Çukurova University, 01250 Sarlçam/Adana, Turkey, \\ *Corresponding author
}

\begin{tabular}{|c|c|}
\hline A R T I C L E I N F O & A B S T R A C T \\
\hline $\begin{array}{l}\text { Keywords: } \\
\text { Anther culture } \\
\text { Genotype } \\
\text { Haploid plant production } \\
\text { Nematode resistance } \\
\text { Cold pre-treatment }\end{array}$ & $\begin{array}{l}\text { Pepper is one of the most cultivated vegetables worldwide and also consumed substantially as a } \\
\text { flavouring ingredient in different culinary traditions. Therefore, many researchers have focused on } \\
\text { its breeding to develop new varieties. One of plant breeding aims is to attain disease and pest } \\
\text { resistance. The use of tissue culture methods in plant breeding has many advantages. The response } \\
\text { of two nematode resistant pepper genotypes to the anther culture and the effect of cold pre-treatment } \\
\text { to the floral buds have been investigated in this study. Alata } 2095 \text { and Alata } 2096 \text { both specified as } \\
\text { resistant to the nematode by Alata Horticultural Research Institute (Alata, Mersin, Turkey) were } \\
\text { used as plant material. Two pre-treatments were used in this study: cold and no cold. In cold } \\
\text { treatment, flower buds were kept in fridge at } 4^{\circ} \mathrm{C} \text { for } 24 \text { hours prior to the anther culture. Murashige } \\
\text { and Skoog medium contained } 0.25 \% \text { activated charcoal, } 6.5 \mathrm{~g} \mathrm{~L}^{-1} \text { agar, } 0.5 \mathrm{mg} \mathrm{L}^{-1} 6 \text {-benzyl-amino- } \\
\text { purine (BAP), } 4 \text { mg } \mathrm{L}^{-1} \text { naphthalene-acetic-acid (NAA), } 15 \mathrm{mg} \mathrm{L}^{-1} \text { silver nitrate (AgNO3), and } 30 \mathrm{~g} \\
\mathrm{~L}^{-1} \text { sucrose was used. After assessment, the highest mean of plant number was } 39.08 \text { per } 100 \text { anthers } \\
\text { for Alata } 2095 \text { genotype. It was } 46.61 \text { and } 31.56 \text { in cold and no cold treatment, respectively. For } \\
\text { Alata } 2096 \text { genotype, the mean was } 1.96 \text { per } 100 \text { anthers }(1.68 \text { and } 2.25 \text { in cold and no cold treatment, } \\
\text { respectively). Statistical analyses confirmed that there was significant difference between } \\
\text { treatments, genotypes and also significant interaction between those factors. At the end of the study, } \\
\text { we can say that Alata } 2095 \text { genotype has a good androgenic response and it can be beneficial in } \\
\text { further pepper breeding studies. }\end{array}$ \\
\hline
\end{tabular}

\section{Introduction}

Pepper (Capsicum annuum L.) is an essential and widely used among other vegetables in different culinary traditions all over the world. Food and Agriculture Organization of the United Nations (FAO) reported that worldwide consumption of vegetables including peppers is increasing and there is change in food consumption patterns (FAO et al., 2012). Those patterns were characterized worldwide by a significant decline of cereals, roots and tubers shares, whereas the shares of fruits, vegetables and animal products increased. Vegetables are building block of a healthy diet. World Health Organization (WHO) and FAO recommend a minimum daily intake of $400 \mathrm{~g}$ of fruits and vegetables. It was also stated in the same report by FAO et al. (2012) that an acceptable consumption of fruits and vegetables also can be beneficial in prevention of micronutrient deficiencies.
Lower level of micronutrients intake ( $<400 \mathrm{~g} /$ day) may increase the risk of chronic diseases. Thus, breeders are very interested in Capsicum not only because of its widespread use all over the world, but also because of its nutritional, cosmetic and beneficial properties (Bosland, 1996).

In order to satisfy the demand in food production for the rising global population, agronomists and plant engineers or breeders have improved plant varieties through different breeding techniques. One of these techniques is termed anther culture and a new generation of plants (hereby pepper plants) is developed directly from male parts of flowers (anthers) without any floral fertilization. This technique is also known as "androgenesis" and in its alternative named as "gynogenesis", only female parts of flower were used. The 
generation obtained after anther culture acquires only one set of parental chromosomes and it is termed "haploid". Haploid plants are important in breeding, because they may express a parental character that is recessive in previous parental generation. Such characters can be a resistance to pests, tolerance to drought and others environmental stresses. The aptitude to induce haploid through anther culture has been found useful and efficient in genetic studies and applied breeding programs. By performing haploidization, homozygous lines of any responsive crop can be generated in one generation (Palma et al., 2015). In the induced androgenesis, primarily goal is to obtain fully homozygote double haploid plants. And it has been reported in many finding that traditional breeding methods take too long time (almost 5 to 6 years or more) compared to modern and current fastest method via anther and/or microspores cultures. The production of haploid and double ploid plants through anther culture of the received hybrids is one of possibilities of the fast stabilization of new variability (Olszewska et al., 2015).

The effectiveness of androgenic response has been enhanced through the years by different research projects conducted in the field of pepper (Capsicum annuum L.) anther culture. Nowadays, as reported by Özkum Çiner and Tıpırdamaz (2002), Buyukalaca et al. (2004), Irikova et al. (2011), Taşkin et al. (2011), Olszewska et al. (2014), Keleş et al. (2015), Keleş et al. (2016) and Ata et al. (2019), some optimizations have been carried out in different ways. For example, in the collection of flower buds, only those having anthers with microspores at late uninucleate or early binucleate stage are selected. Another optimization is on the floral bud stress treatment prior to anther culture (cold or heat treatment) and even the optimization of the induction media by slightly modifying the composition of MS (Murashige and Skoog, 1962) basal medium (supplemented with $0.25 \%$ activated charcoal, $4 \mathrm{mg} \mathrm{L}^{-1}$ naphthalene-acetic-acid (NAA), $0.5 \mathrm{mg} \mathrm{L}^{-1}$ 6-benzylamino-purine (BAP), $6.5 \mathrm{~g} \mathrm{~L}^{-1}$ agar, $30 \mathrm{mg} \mathrm{L}^{-1}$ sucrose and $15 \mathrm{mg} \mathrm{L}^{-1}$ silver nitrate $\left.\left(\mathrm{AgNO}_{3}\right)\right)$. It was reported by Ata et al. (2019) that embryo formation frequency rate from anther culture is currently at $66.36 \%$ in Turkey (depending on genotypes and seasons) compared to the ratio that they use to have in early 80 's which was 0.05 to $0.1 \%$.

Root-knot nematode (Meloidogyne spp.) is an important parasitic group affecting pepper worldwide and causes significant yield losses. In recent years, various independent dominant resistance genes (Me genes) have been found and transferred to different cultivated forms and new genitors were developed to use in breeding programs (Fazari et al., 2012). Our aim in this study is to determine the response of two nematode resistant pepper genotypes Alata 2095 and Alata 2096 to anther culture and to test if cold applications as pre-treatment will increase the androgenetic success. If we can determine the response of these genotypes to anther culture, we may be able to program the breeding strategy in a shorter time and more effectively. In this case, we can save both time and labor, and also we can provide more homozygosity than classic methods obtained homozygosity at a certain rate with selfing of plants every year. Since most of private companies have tissue culture laboratories, results of such studies can be transferred to the practice and the economy and such studies are supported by private companies.

\section{Materials and Methods}

\section{Plant Materials}

Two pepper genotypes determined as nematode resistant; "Alata 2095" and "Alata 2096" (nematode resistance of these genotypes was detected within the Scientific and Technological Research Council of Turkey (TÜBİTAK) project numbered "109G096") were used as plant materials and they were grown in greenhouse located in Alata Horticultural Research Institute (ALATA, Erdemli-Mersin, Turkey). Pepper seedlings were transferred in early September 2016 into the greenhouse equipped with drip irrigation system. Thus irrigation was done regularly and $100 \mathrm{~kg} \mathrm{ha}^{-1}$ NPK (18:18:18) fertilizer with trace elements was applied once on the newly adapted pepper seedlings. They were grown under natural photoperiodicity with temperature ranges of $16^{\circ} \mathrm{C}$ to $25^{\circ} \mathrm{C}$ in daylight and $12^{\circ} \mathrm{C}$ to $20^{\circ} \mathrm{C}$ in the night.

\section{Flower Buds Collection and Anther Excision}

The best time to collect floral buds has been revealed by Olszewska et al. (2014) and Taşkın et al. (2016). The most proper flower bud stage can be determined morphologically as when the corolla has the same size as calyx or are few inches longer. In this stage, microspores are in the beginning of the first mitotic division (either in late uninucleate or early binucleate phase). Also the proper size of flower bud as reported by Taşkin et al. (2016), it is when the flower bud has $5 \mathrm{~mm}$ of diameter and $7 \mathrm{~mm}$ in length. By investigating on different bud size and their morphological features, Özkum Çiner and Tıpırdamaz (2002) found that buds at the same developmental stage (5 $\mathrm{mm}$ of diameter and $7 \mathrm{~mm}$ in length) was also the convenient development stage in pepper androgenesis.

Flower buds were collected from donor plant directly from greenhouse in fall season 2016 (end of November). They were collected and kept under safe conditions (temperature and moisture) using plastic bags and immediately transported to the laboratory in the same approach as Olszewska et al. (2014). The sanitation (disinfection) step was done using a $10 \%$ sodium hypochlorite $(\mathrm{NaOCl})$ solution for $15 \mathrm{~min}$, and then buds were rinsed (four times) thoroughly in sterile distilled water. All these were performed in aseptic condition using a laminar flow hood where by anthers were excised from floral buds.

\section{Temperature Stress Treatment}

In this study, two different types of temperature application were performed; cold treatment to the floral buds and heat treatment to anthers cultured. Cold pretreatment was applied to flower buds before anther culture at $4^{\circ} \mathrm{C}$ of temperature during 24 hours comparatively with control (no cold application). Heat treatment was done for all cultures at $35^{\circ} \mathrm{C}$ temperature during 48 hours after placing the anthers on the medium.

\section{Basal Media Supplements}

Two kinds of media were prepared for this experimental work and their compositions are shown in Table 1. The first medium named "Induction Medium" is a basal medium also known as Murashige and Skoog (MS) supplemented with different exogenous elements 
(Murashige and Skoog, 1962). The second medium named "Differentiation Medium" is also a basal medium (MS) supplemented with only by vitamin, agar and sucrose which will be conducive to the development of embryos. Both media in this research work were set on 5.8 of $\mathrm{pH}$.

\section{Induction of Anthers on Media and Their Incubation}

After the flower buds were scrutinized and the filaments were removed in the laminar flow hood, placement of anthers on the proper media was performed carefully in order to avoid anthers sinking below the media surface. Before petri dishes placement into an incubator, they are sealed. Depending on the species being cultured, a given specific temperature and photoperiodicity is set out on the incubator (Reed, 2005).

The most suitable temperature degrees for incubation are $4^{\circ} \mathrm{C}$ for cold and $35^{\circ} \mathrm{C}$ for hot temperature conditions as revealed by Keleş et al. (2016). In this study, we followed the same procedure by Taşkin et al. (2011) in which during the first two days cultured anthers were incubated at $35^{\circ} \mathrm{C}$. Afterward they were transferred to the growth chamber at $28^{\circ} \mathrm{C}$ with a periodicity 8 hours dark over 16 hours light. And by quoting Irikova et al. (2016), a shorter period of incubation in darkness decrease callus formation. Stated differently, it promotes the direct pathway over the indirect pathway.

\section{Germination of Embryos}

The fundamental in this process is the successful emancipation of embryo-like structure. And the acquisition of embryogenic potential is one of three phases that constitutes androgenic development along with, induction of cell division and formation of structure (Irikova et al., 2016). By using the same procedure as Keleş et al. (2015) and Ar1 et al. (2016), $15 \mathrm{~cm}$ glass tubes containing hormone-free MS nutrient medium were used as transfer container for all embryos obtained from anthers cultured.

\section{Ploidy Screening}

The reliable estimation of ploidy level in plants using flow cytometry has never been an easy task. It is an evaluation of microscopic particles in suspension, which are confined and submitted on an ardent light bim. The resulting flow induce fluctuated and dissipated fluorescent light which are then collected and converted to electric current pulses by optic sensors and organized. For the purpose of ploidy estimation (or determination of nuclear DNA content), a DNA specific fluorochrome is used to stain nuclei and/or permeabilized cells in suspensions. The result of analysis is done by quantifying the all amount of light emitted by each sole nucleus. And histogram representing relative DNA content and corresponding relative fluorescence intensity is disclosed (Doležel and Bartoš, 2005). According to Ochatt (2006), flow cytometry has substantiated itself as practical, handy and profitable in ploidy determination. It has been used in these recent years to inspect different species ploidy level and relative DNA content because is cheap (low cost per sample).

Assay procedure and sample preparation are done as follow; (i) $400 \mu \mathrm{l}$ of extraction buffer is added to approximately $0.5 \mathrm{~cm}^{2}$ of leaf tissue in petri dish. (ii) The sample material is chopped by using a harsh razor blade and then incubated for 30 to 60 seconds. (iii) Sample are filtered using special filter (Partec $50 \mu \mathrm{m}$ Cell Trics ${ }^{\circledR}$ ), then $1.6 \mathrm{ml}$ of staining buffer is added to the sample tube. (iiii) Followed by a short incubation of 30 to 60 seconds, then sample analysis in flow cytometer.

\section{Experimental Design and Data Analysis}

In this study, the androgenic response was tested for two different pepper genotypes with two different pretreatments. And the experiment was designed in a completely randomized experimental design with 10 replications (each replication consists of seven petri dishes containing most of the time five anthers taken from one floral bud) by each genotype in two distinct treatments. The data of plant number obtained were investigated with a statistical software JMP version 5.0.1 (SAS Institute Inc., Cary, NC). Analyze of variances (ANOVA) was conducted to figure out the effects of the different genotypes and pretreatments. Differences among groups were inspected by a slightest significant difference test. Contrasts that have been generated $\mathrm{P} \leq 0.05$ were regarded as statistically significant. Statistical analyses were not applied to the number of embryos obtained because they did not conform to the statistics. In anther culture studies, if no embryos can be obtained from any of the anthers in a petri dish and this situation increases, statistical analyzes can be misleading.

Table 1 Composition of nutrient media used for anther culture of pepper

\begin{tabular}{l|cc}
\hline \multirow{2}{*}{ Compound } & \multicolumn{2}{|c}{ For Treatment I and II } \\
\cline { 2 - 3 } & $\begin{array}{c}\text { Induction } \\
\text { Medium }\end{array}$ & $\begin{array}{c}\text { Differentiation } \\
\text { Medium }\end{array}$ \\
\hline Basal Medium & MS & MS \\
$\mathrm{NAA}^{*}$ & 4 & - \\
$\mathrm{BAP}^{*}$ & 0.5 & - \\
$\mathrm{AgNO}_{3} *$ & 15 & - \\
Activated charcoal** $_{\text {Agar }}^{* * *}$ & $0.25 \%$ & - \\
Sucrose*** & 6.5 & 6.5 \\
Vitamin $* * * *$ & 30 & 30 \\
$*$ mg L & of concentration, ** Percentage (\%), *** $\mathrm{g} \mathrm{L}^{-1}$ of concentration, \\
$* * * * \mathrm{ml} \mathrm{L}^{-1}$ of concentration & \multicolumn{2}{l}{}
\end{tabular}

\section{Results}

\section{Stage}

Effectiveness of Embryogenesis Induction in the Early

After a period of 35 days of incubation in darkness, we started to observe embryo formation in the both genotypes. Total embryo number and percentage obtained from both genotypes and two pre-treatments during all culture period were presented in Table 2. And also weekly number of embryo was given in Figure 1 detailed. Recorded data showed that Alata 2095 genotype has a good response regarding embryo formation. Results appear to be quite clear in terms of the response of genotypes to anther culture. However, it is not possible to say the same things for pre-treatment effects. While the cold stress increased the number of embryo in Alata 2095 genotype, decrease was observed in Alata 2096 genotype. However, this decline was not as sharp as the rise in the other genotype. 
Table 2 Frequency of embryo formation from anthers in both two pepper genotypes

\begin{tabular}{c|cccrr}
\hline Treatments & Genotypes & Number of petri & $\begin{array}{c}\text { Number of } \\
\text { cultured anthers }\end{array}$ & $\begin{array}{c}\text { Frequency of formed embryos } \\
\text { Number - Percentage } \%\end{array}$ \\
\hline \multirow{2}{*}{ With cold stress $\left(+4^{\circ} \mathrm{C}\right)$} & Alata 2095 & 70 & 354 & 196 & 55.37 \\
& Alata 2096 & 70 & 356 & 7 & 1.97 \\
\multirow{2}{*}{ Without cold stress } & Alata 2095 & 70 & 358 & 128 & 35.75 \\
& Alata 2096 & 70 & 355 & 9 & 2.53 \\
\hline
\end{tabular}

Table 3 Frequency of plant regeneration in anther culture of Alata 2095 and Alata 2096 genotypes

\begin{tabular}{|c|c|c|c|c|}
\hline Treatments & Genotypes & Number of cultured anthers & \multicolumn{2}{|c|}{$\begin{array}{c}\text { Frequency of formed seedlings } \\
\text { Number - Percentage } \%\end{array}$} \\
\hline \multirow{2}{*}{ With cold stress $\left(+4^{\circ} \mathrm{C}\right)$} & Alata 2095 & 354 & 165 & 46.61 \\
\hline & Alata 2096 & 356 & 6 & 1.68 \\
\hline \multirow{2}{*}{ Without cold stress } & Alata 2095 & 358 & 113 & 31.56 \\
\hline & Alata 2096 & 355 & 8 & 2.25 \\
\hline
\end{tabular}

Table 4 Seedling formation from two treatment and two pepper genotypes tested

\begin{tabular}{l|ccc}
\hline \multirow{2}{*}{ Treatments } & \multicolumn{3}{c}{ Genotypes } \\
\cline { 2 - 4 } & Alata 2095 & Alata 2096 & Treatment mean \\
\hline With cold stress $\left(+4^{\circ} \mathrm{C}\right)$ & $3.75^{\mathrm{a}}$ & $0.15^{\mathrm{c}}$ & $1.95^{\mathrm{a}}$ \\
Without cold stress & $2.75^{\mathrm{b}}$ & $0.20^{\mathrm{c}}$ & $1.475^{\mathrm{b}}$ \\
Genotype mean & $3.25^{\mathrm{a}}$ & $0.175^{\mathrm{b}}$ & \\
\hline
\end{tabular}

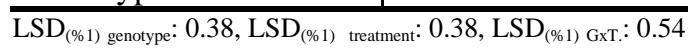

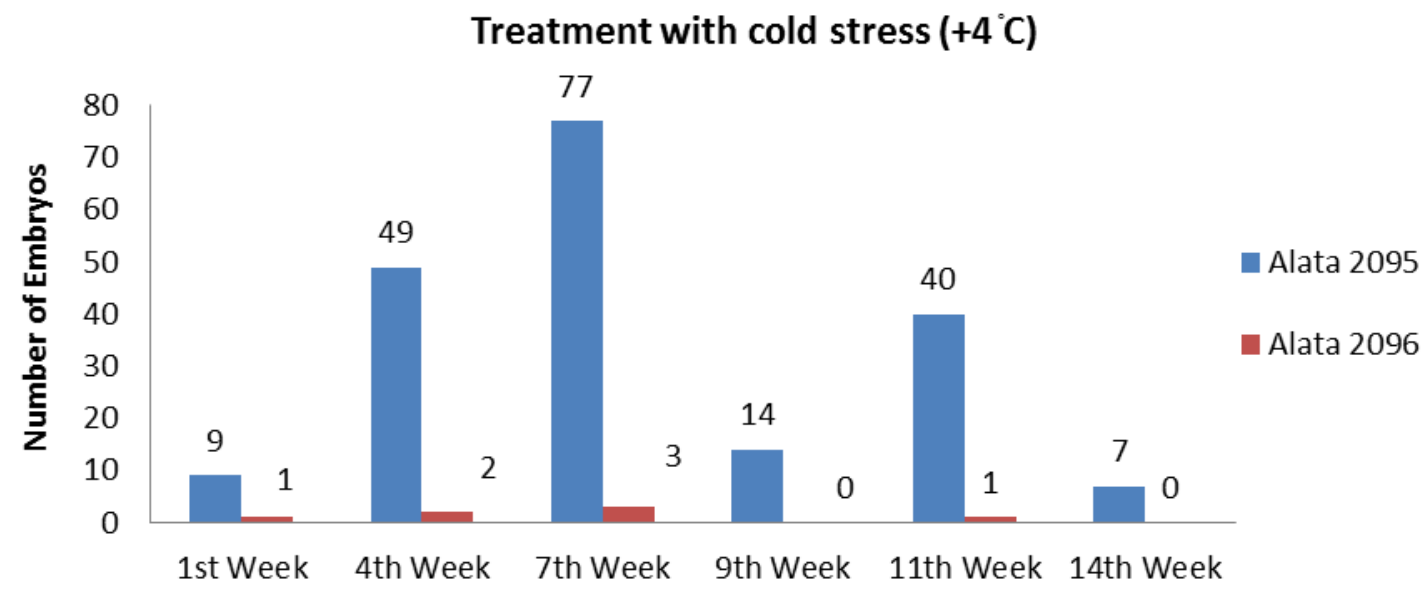

Treatment without cold stress

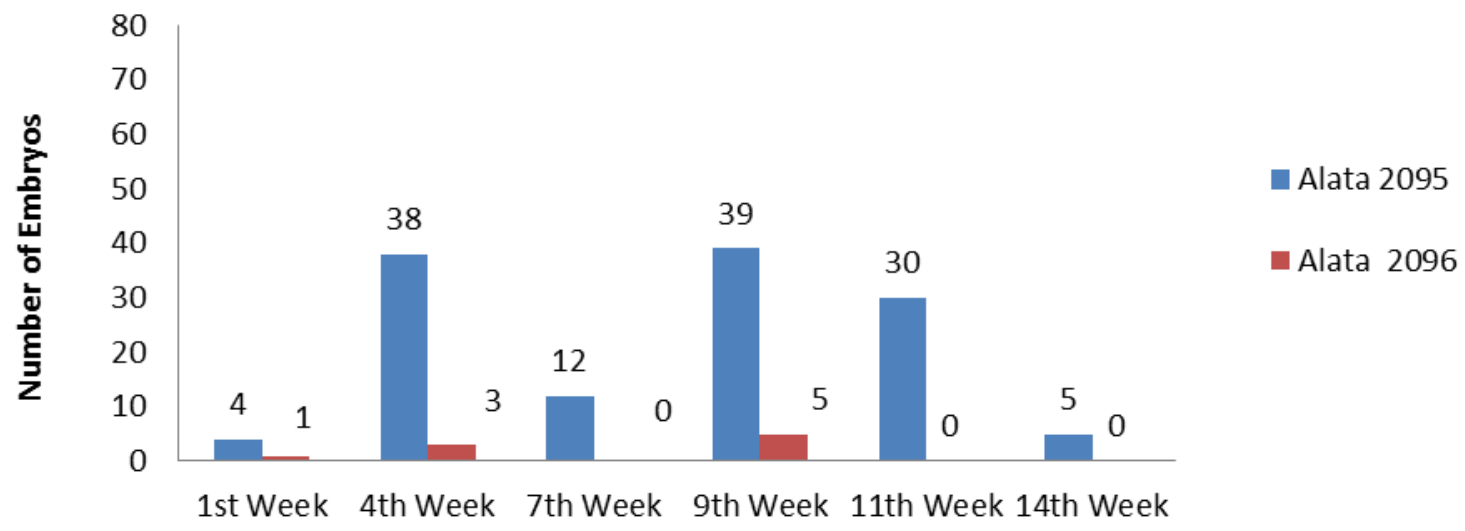

Figure 1 Results of weekly embryo observation of two nematode resistant pepper genotypes (Alata 2095, Alata 2096) (A) subjected cold stress at $4{ }^{\circ} \mathrm{C}$ as pre-treatment (B) without any pre-treatment 
The Overall Androgenic Response of the Two Studied Pepper Genotypes

The overall effectiveness of the anther culture of the two genotypes and factors (treatment and genotype) interaction were assessed by calculating the frequency of formed or regenerated seedlings as shown in Table 3 and Table 4. Also in vitro plants obtained were presented in Figure 2. The recorded data shows that Alata 2095 genotype has a good response regarding embryos formation and seedlings regeneration. From these two genotypes tested, only Alata 2095 showed the ability to produce more mature embryos and/or seedlings. In other words, it has shown a good androgenic response. But in order to confirm if the factor "treatment" and/or "type of genotypes" have an influence in these results obtained, a statistical analysis was necessary. Based on the statistical analyses, we found that there was also significant difference between treatments (cold and no cold treatments). That means that factor "treatment" has influence on the result obtained. When we looked more close to the genotype level, we found a significant difference within pepper genotypes (Alata 2095 and Alata 2096). At the interaction level, we observed also significant interaction between treatments and genotypes. All factors were dependent; they influenced each other. Based on statistical analysis, we can clearly say that Alata 2095 genotype subjected to cold pre-treatment gives the best results.

\section{Flow Cytometric Analysis of Anther-Derived Pepper Plantlets}

In this study, two different genotypes and two different treatments were applied to calculate the rate of spontaneous doubled haploidy in peppers. For Alata 2095 genotype, in both two treatments (cold and no cold treatments), 20 seedlings were randomly selected and analyzed from the final population (which was 113 and 165 pepper seedlings). For Alata 2096 genotype, only five seedlings were selected and analyzed (only in the no cold treatment) from a total population of eight pepper seedlings. In cold treatment, all five seedlings obtained were too young for any ploidy analysis. The rate of spontaneous doubled haploid pepper was shown in Table 5. It was found that the highest rate was $20 \%$ for Alata 2096 genotype in no cold treatment, followed by $15 \%$ for Alata 2095 genotypes also in the cold treatment and finally the lowest rate was $5 \%$ for Alata 2095 genotype in the cold treatment.

Table 5 Ploidy level results (\%) of two pepper genotypes obtained via anther culture

\begin{tabular}{c|lrrrrr}
\hline \multirow{2}{*}{ Genotypes } & \multicolumn{2}{c}{ Treatments } & Sample & \multicolumn{2}{c}{ Haploid } & \multicolumn{2}{c}{ Diploid (SDH) } \\
\cline { 4 - 7 } & & size & Number & $\%$ & Number & $\%$ \\
\hline \multirow{2}{*}{ Alata 2095} & Cold treatment $\left(+4^{\circ} \mathrm{C}\right)$ & 20 & 19 & 95 & 1 & 5 \\
\multirow{3}{*}{ Alata 2096} & No cold treatment & 20 & 17 & 85 & 3 & 15 \\
& Cold treatment $\left(+4^{\circ} \mathrm{C}\right)$ & - & - & - & - & - \\
\hline
\end{tabular}

*SDH: Spontaneous double haploid
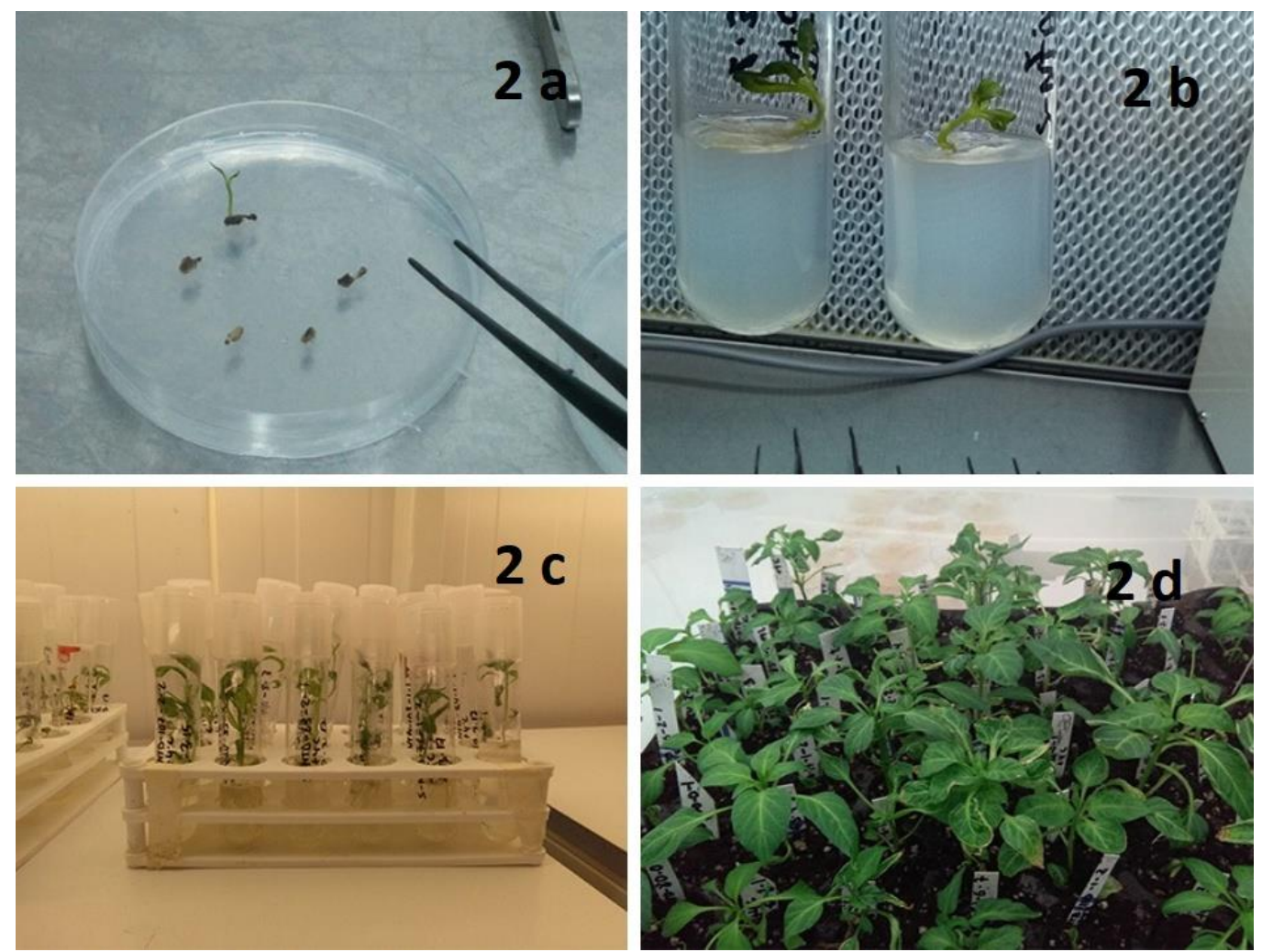

Figure 2 (2a) embryos germinated in petri dishes (2b-2c) in vitro pepper plants obtained from embryos via anther culture (2d) acclimatized young pepper plants 


\section{Discussion}

It has been revealed by Irikova et al. (2011) and Olszewska et al. (2014) that a physical (low or high temperature) or physiological (starvation and/or osmotic) stress can be applied to flower buds prior to anther isolation and induction to medium. And the exposure to such stress can significantly affect the developmental pathways, switching from microspore gametophyte to sporophyte embryo stage. It was also reported by Olszewska et al. (2014) that when $+4^{\circ} \mathrm{C}$ temperature for 48 hours is applied as pre-treatment to flower buds, results improve of 1 to 3 plants per 100 anthers during embryogenesis. Cold pretreatment to flower buds from 24 to 100 hours before excising of anthers have stimulated androgenic response, however opposite reaction may happen in some case due to different genotypes studied and experimental conditions. It was also determined by Irikova et al. (2011) that during the first two days of anther culture if there is an application of high temperature $\left(35^{\circ} \mathrm{C}\right)$, embryogenesis is more efficiently stimulated compared to cold $\left(4^{\circ} \mathrm{C}\right)$ pretreatment of floral buds. In this study, we have found that the stress pre-treatment by cold (low temperature at $4{ }^{\circ} \mathrm{C}$ ) application to flower buds before anther culture has significant effects on embryogenesis of both studied genotypes, although the opposite results were found by Özkum et al. (2001) and Kim et al. (2005). It was emphasized by Özkum Çiner and Tıpırdamaz (2002) that cold treatment to the pepper flower buds did not increase embryo formation.

Media composition has been optimized through the years as reported in many different studies such as Özkum Çiner and Tıpırdamaz (2002), Taşkin et al. (2011), Olszewska et al. (2014), Keleş et al. (2015), Arı et al. (2016). The aim of adding some plant growth regulators to Murashige and Skoog (MS) basal medium is to enhance the development of androgenic embryo in some recalcitrant genotypes. Irikova et al. (2011) has displayed different roles of activated charcoal in anther culture. It acts essentially in the absorption of phenols and abscisic acid which are inhibitory to microspore during embryogenesis. By inhibiting callus proliferation, it can perpetuate vitality and productivity of anthers. Sometimes, ethylene is released during in vitro plant tissue culture and in this case silver nitrate is used as inhibitor. Buyukalaca et al. (2004) obtained an improvement in embryonic induction only by using a concentration of $15 \mathrm{mg} \mathrm{L}^{-1} \mathrm{AgNO}_{3}$. They got an average of 45.7 embryos per 100 anthers.

Different approaches were used in order to measure the level of androgenic response of these nematodes resistant pepper genotypes, Alata 2095 and Alata 2096. By calculating the frequency of embryos formation, we found following results: (i) for Alata 2095 genotype, 55.37 and 35.75 embryos per 100 anthers, 46.61 and 31.56 seedlings per 100 anthers were obtained from cold and no cold treatments, respectively. (ii) for Alata 2096 genotype, 1.97 and 2.53 embryos per 100 anthers, 1.68 and 2.25 seedlings per 100 anthers were recorded in cold and no cold treatments, respectively. This low rate of embryos displayed by Alata 2096 can be less than $10 \%$ as observed by Olszewska et al. (2014) during the assessment on the effectiveness of in vitro androgenesis of seventeen Capsicum genotypes grown in Poland and their results were between 0 and $16 \%$. And some genotypes were nonresponsive to in vitro androgenesis confirming the recalcitrant nature of Capsicum species in that regard. By carrying out a statistical analysis, it was finally possible to conclude. The androgenic response was genotype dependent. Meaning that success of anther culture is driven by genotype. Same remark was pinpointed by Keleş et al. (2016), when they compared different pepper genotypes originated from Turkey and other countries. Also when Taşkin et al. (2011) and Ata et al. (2019) assessed the induction of microspore-derived embryos by anther culture, they found the same genotype dependence of anther culture. Different literature studies such as Irikova and Rodeva (2004) and Koleva-Gudeva et al. (2007) have confirmed this dependence. Irikova and Rodeva (2004) investigated in vitro response of anther culture of Bulgarian pepper lines, varieties and hybrids. They obtained considerable variation in different genotypes cultured in different media.

During this study, a few spontaneous double haploid lines were produced. The mean of spontaneous double haploids lines (SDHs) was $13 \%$ and varied between $5 \%$ and $20 \%$. This result is low but it still in range of all anther culture projects carried out in Turkey. As revealed by Taşkin et al. (2016), results of SDHs varied between 8.3 and $61 \%$ depending on the type and genotype of pepper studied in Turkey. Keleş et al. (2015) assessed the effect of pepper types on the production of spontaneous double haploid lines via anther culture and they found $22.2 \% \mathrm{SDH}$ in green pepper types. This is closer to our Alata 2096 genotype (in no cold treatment) which had about $20 \%$ of $\mathrm{SDH}$. Double haploid lines are invaluable elements in modern breeding methods due to their guaranteed and completely homozygous nature (Irikova et al., 2016). It is important to produce considerable number of genetically stable lines like double haploid (DH). It has been reported by Irikova et al. (2011) that in order to assist restoration of recessive mutations and unique genetic recombination in breeding program, haploid plant production is also useful. The same importance has been emphasized by Irikova et al. (2016). They stated that sometimes haploid lines are incorporated in breeding projects for gene mapping and in detection of convenient recessive mutation.

Disease and pest resistance is an essential breeding goal in pepper as in most plant species. Nematode is one of the pests that cause serious yield and quality losses in pepper. For this reason, it is important to determine nematode resistant genetic resources for private companies in terms of future breeding studies of pepper. After the detection of these genotypes, determining of their anther culture performance will be important in accelerating the breeding studies. In this study, the anther culture performance of Alata 2095 and Alata 2096 genotypes identified as resistant to the nematode were determined. While the response of Alata 2095 genotype was high, Alata 2096 genotype was weak. This means that we can recommend Alata 2095 genotype to private companies focused on pepper breeding for nematode resistance and research institute having tissue culture opportunities. This information will be very useful for them to save time. This study includes not only scientifically but also practical and economically important 
information. The results and lines obtained from this study have been shared with a national private seed and breeding company under a joint project.

\section{Conclusion}

In last decades, anther culture has often been used as a breeding tool and its importance in pepper crop has been emphasized in many studies. Anther culture is also an important technique used in germplasm collection to support breeding effort (Reifschneider et al., 2013). In this study, androgenic response of two nematode resistant pepper genotypes was assessed and the results obtained clearly showed that anther culture response was affected by genotype. Among these two genotypes; Alata 2095 and Alata 2096, only Alata 2095 was more responsive. It was also observed that there was effect of cold stress treatment (at $+4^{\circ} \mathrm{C}$ ) on androgenic response of both two studied genotypes. This effect was more prominent in Alata 2095 genotype with 55.37 embryos per 100 anthers and 46.61 seedlings per 100 anthers. For Alata 2096 genotype, we can clearly say that if the response of this genotype to the anther culture could be better, the effect of cold application on this genotype would be better observed. It is important to determine the anther culture response of a pepper genotype. It speeds up the selection efficiency and homozygous line production. As notify by Murovec and Bohanec (2012), homozygosity achieved only in one generation has a greater advantage in modern breeding due to the elimination of several generations of self-pollination.

\section{Acknowledgement}

The authors express their appreciation to the late Prof. Dr. Saadet Büyükalaca, whose contribution to this work was of great significance. The authors also thank to Serhat Yıldız, Emrah Kaymakçı and Haluk İhsan Tekin from Alata Horticultural Research Institute for their technical assistance and valuable help. They would also like to thank Çukurova University Scientific Research Projects Coordinating Office (FBA-2017-7761) for its financial support.

\section{References}

Arı E, Yıldırım T, Mutlu N, Büyükalaca S, Gökmen Ü, Akman E. 2016. Comparison of different androgenesis protocols for doubled haploid plant production in ornamental pepper (Capsicum annuum L.). Turk. J. Biol. 40(4): 944-954. DOI: https://doi.org/10.3906/biy-1509-36

Ata A, Keleş D, Taşkın H, Büyükalaca S. 2019. Effects of season, genotype, and nutrient medium on pepper anther culture and microspore development. Turk. J. Agric. For. 43(2): 123-137. DOI: https://doi.org/10.3906/tar-1802-35

Bosland PW. 1996. Capsicums: Innovative Uses of an Ancient Crop. In: Janick J. (ed.). Progress in New Crops. Arlington, USA: ASHS Press, 479-487.

Buyukalaca S, Comlekcioglu N, Abak K, Ekbic E, Kilic N. 2004. Effects of silver nitrate and donor plant growing conditions on production of pepper (Capsicum annuum L.) haploid embryos via anther culture. Eur. J. Hortic. Sci. 69(5): 206209.

Doležel J, Bartoš J. 2005. Plant DNA flow cytometry and estimation of nuclear genome size. Ann Bot-London 95(1): 99-110. DOI: https://doi.org/10.1093/aob/mci005
FAO, WFP, IFAD. 2012. The State of Food Insecurity in the World Economic growth is necessary but not sufficient to accelerate reduction of hunger and malnutrition. Rome, Italy: Food and Agriculture Organization of the United Nations.

Fazari A, Palloix A, Wang L, Yan Hua M, Sage-Palloix AM, Zhang BX, Djian-Caporalino C. 2012. The root-knot nematode resistance $\mathrm{N}$-gene co-localizes in the $\mathrm{M}$-genes cluster on the pepper (Capsicum annuum L.) P9 chromosome. Plant Breeding131(5): 665-673. DOI: https://doi.org/10.1111 j.1439-0523.2012.01994.x

Irikova T, Grozeva S, Rodeva V. 2011. Anther culture in pepper (Capsicum annuum L.) in vitro. Acta Physiol. Plant 33(5). DOI: https://doi.org/10.1007/s11738-011-0736-6

Irikova T, Kintzios S, Grozeva S, Rodeva V. 2016. Pepper (Capsicum annuum L.) anther culture: fundamental research and practical applications. Turk. J. Biol. 40: 719-726. DOI: https://doi.org/10.3906/biy-1506-79

Irikova T, Rodeva V. 2004. Anther culture of pepper (Capsicum annuum L.): The effect of nutrient media. Capsicum and Eggplant Newsletter 23: 101-104.

Keleş D, Pınar H, Ata A, Taşkın H, Yıldız S, Büyükalaca, S. 2015. Effect of pepper types on obtaining spontaneous doubled haploid plants via anther culture. HortScience 50(11): 1671-1676. DOI: https://doi.org/10.21273 /HORTSCI.50.11.1671

Keleş D, Pinar H, Taşkin H, Büyükalaca S. 2016. Comparison of pepper genotypes originated from Turkey and the other countries for anther culture response. In: Ertsey-Peregi K, Füstös Z, Palotás G, Csilléry G. (eds.). Proceedings of XVIth EUCARPIA Capsicum and Eggplant Working Group Meeting, Kecskemét, Hungary, 12-14 September 2016, Diamond Congress Ltd., 275-281.

Kim J, Kim Y, Yi G, Kim K. 2005. Anther culture of transgenic pepper (Capsicum annuum L.). Korean J. Breed. 37(4): 241-246.

Koleva-Gudeva LR, Spasenoski M, Trajkova F. 2007 Somatic embryogenesis in pepper anther culture: The effect of incubation treatments and different media. Sci HorticAmsterdam 111(2): 114-119. DOI: https://doi.org/10.1016 /j.scienta.2006.10.013

Murashige T, Skoog F. 1962. A revised medium for rapid growth and bio assays with tobacco tissue cultures. Physiol. Plantarum 15(3): 473-497. DOI: https://doi.org/10.1111 /j.1399-3054.1962.tb08052.x

Murovec J, Bohanec B. 2012. Haploids and Doubled Haploids in Plant Breeding. In: Abdurakhmonov IY. (ed). Plant Breeding. London, United Kingdom: IntechOpen Limited, 87-106. ISBN 978-953-307-932-5

Ochatt SJ. 2006. Flow Cytometry (ploidy determination, cell cycle analysis, DNA content per nucleus). Dijon INRA, France: Medicago Truncatula Handbook.

Olszewska D, Jedrzejczyk I, Nowaczyk P, Sendel S, Gaczkowska B. 2015. In vitro colchicine treatment of anther-derived pepper haploids. Bulg. J. Agric. Sci. 21(4): 806-810.

Olszewska D, Kisiala A, Niklas-Nowak A, Nowaczyk P. 2014. Study of in vitro anther culture in selected genotypes of genus Capsicum. Turk. J. Biol. 38(1): 118-124. DOI: https://doi.org/10.3906/biy-1307-50

Özkum Çiner D, Tıpırdamaz R. 2002. The effects of cold treatment and charcoal on the in vitro androgenesis of pepper (Capsicum annum L.). Turk. J. Biol. 26: 131-139.

Özkum D, Tıpırdamaz R, Ellialtioğlu S. 2001. The relationship between the endogenous abscisic acid content of anthers and in vitro androgenesis in peppers (Capsicum annuum L.). Acta Hortic. (560): 327-329. DOI: https://doi.org/10.17660 /ActaHortic.2001.560.63

Palma JM, Sevilla F, Jiménez A, del Rio LA, Corpas FJ, Álvarez de Morales P, Camejo DM. 2015. Physiology of pepper fruit and the metabolism of antioxidants: chloroplasts, mitochondria and peroxisomes. Ann. Bot-London 116(4): 627-636. DOI: https://doi.org/10.1093/aob/mcv121 
Reed SM. 2005. Haploid Cultures. In: Trigiano RN, Gray DJ. (eds.). Plant Development and Biotechnology. Washington DC, USA: CRC Press LLC, 225-234. ISBN-10:0849316146.

Reifschneider FJB, Ribeiro CSC, Carvalho SI. 2013. Development of new Capsicum cultivars at Embrapa (Brazil). In: Lanteri S, Rotino GL. (eds.). Meeting on Genetics and Breeding of Capsicum and Eggplant EUCARPIA, Torino, Italy, 2-4 September 2013, Embrapa Hortaliças - Artigo em anais de congresso (ALICE), 71-78.
Taşkin H, Büyükalaca S, Keleș D, Ekbiç E. 2011. Induction of microspore-derived embryos by anther culture in selected pepper genotypes. Afr. J. Biotechnol. 10(75): 17116-17121. DOI: https://doi.org/10.5897/AJB11.2023

Tașkın H, Keleș D, Baktemur G, Büyükalaca S. 2016. Scientific contributions to anther culture of pepper from Turkey. In: Ertsey-Peregi K, Füstös Z, Palotás G, Csilléry G. (eds.). Proceedings of XVIth EUCARPIA Capsicum and Eggplant Working Group Meeting, Kecskemét, Hungary, 12-14 September 2016, Diamond Congress Ltd., 568-573. 